\title{
Express-evaluation as tool of investment solution in telecommunication industry
}

\author{
Larisa Zubkova \\ Department of Finance, money and credit \\ Tyumen state University \\ Tyumen, Russia \\ Lasasha@rambler.ru
}

\author{
Sergey Dyachkov \\ Department of Finance, money and credit \\ Tyumen state University \\ Tyumen, Russia
}

\begin{abstract}
Currently, one of the key global trends in the world of progress is the intensive development of the information and communication technologies, ensuring stable economic growth, raising living standards and creating a knowledge economy. The rapid growth of the Telecom industry and development of methodology of investment analysis in this industry has led to the advanced contribution and development of this article. The paper proposes a scheme of the part of investment analysis that includes two important, complementary components of macroeconomic and microeconomic. It provides the calculation of the indicator for the assessment of companies within the telecommunications industry. The article presents a comparative analysis by the calculation of market discounts of the company's values to the industry's average values based on the related financial records and the most common financial ratios. It includes the correlation analysis of estimates of market discount based on the different indicators, including special industry indicator. The results of the study can be used to carry out rapid assessment of companies of the telecommunications industry and compare them in the framework of the sectoral analysis.
\end{abstract}

Keywords-investments, industry, information and communication technologies, investment industrial analysis, indicator for express-evaluation, telecommunication industry

\section{INTRODUCTION}

A breakthrough in some of the most important scientific and technological fields, especially in the field of electronics, cybernetics, cybersecurity and computer science, had a powerful impact on the computerization of all the aspects of society's life.

The transition from an industrial era to an information society, as well as transformation of frameworks for value estimation of information in political and economic life of country was the results of computerization and swift progress of information and telecommunication technologies. Progress of information and telecommunication technologies and subsequent automation and computerization of the business processes permits solution of many complex problems.

Wide spreading and rapid development of information technologies become a global driving force of the world progress in recent decades. Nowadays, information and computing technologies (ICT) influence the economic progress. ICT promotes investment attraction, creates new jobs, introduces progressive technologies in the production and management, and ultimately creates innovative economy, provides stable economic growth and rises standards of living.

Formation of neo-industrial society with its features of knowledge economy, intellectual labor, the automation and computerization of production, brought Russian telecommunication industry to the growth.

\section{CURRENT STATE OF TELECOMMUNICATION INDUSTRY IN RUSSIA}

The telecommunication industry, like the market economy, in Russia is contradictory and young. This industry consists of several markets by services: backbone networks, phone landlines, internet landlines, cell networks, satellite networks, cable, digital and mobile TV broadcasting networks.

Each market has independent client base, but interdependent in technological basis (except satellite, which is very specific). Because of this, telecommunication markets have different types of competition (some of these are monopolistic, others are oligopolistic) and require different investment strategy, but at the same time all of them are interdependent [1].

Fundamentally, telecommunication industry is quite attractive because the products of the industry (communication service) are the consumer goods of regular use and the offered product's market is steadily growing.

The development of the industry under review connected to the high marketability and demand of services, which confirmed by:

- the positive dynamic of the volume of rendered telecommunication services;

- the positive dynamic of the use of ICT by government and business. 
Along with this, the industry is looking into additional resources, which is confirmed by:

- a quite significant proportion of loss-making companies;

- a high degree of depreciation of fixed assets (over 63\%) and a systematic reduction of the its regeneration rate;

- a lower level of capital expenditure on ICT than it is demanded. ${ }^{1}$

TABLE I. AGGREGATED FINANCIAL STATEMENTS OF RUSSIAN TELECOMMUNICATION INDUSTRY ${ }^{2}$

mln. rubles

\begin{tabular}{|c|c|c|c|c|}
\hline \multirow{2}{*}{ Item } & \multicolumn{4}{|c|}{ Year } \\
\cline { 2 - 5 } & $\mathbf{2 0 1 0}$ & $\mathbf{2 0 1 2}$ & $\mathbf{2 0 1 4}$ & $\mathbf{2 0 1 5}$ \\
\hline \multirow{2}{*}{ Revenue } & 1204 & 1367 & $\begin{array}{c}1478 \\
579\end{array}$ & $\begin{array}{c}1511 \\
849\end{array}$ \\
\hline Amortization & 170897 & 198121 & 243530 & 264512 \\
\hline OIBDA & 455103 & 508338 & 555829 & 544828 \\
\hline Net income & 189349 & 172221 & 165731 & 114868 \\
\hline Financial debt & 654712 & 950927 & $\begin{array}{c}1228 \\
596\end{array}$ & $\begin{array}{c}1136 \\
892\end{array}$ \\
\hline Net debt & 583374 & 884238 & $\begin{array}{c}1036 \\
685\end{array}$ & $\begin{array}{c}1014 \\
694\end{array}$ \\
\hline Book Value & 872881 & 708400 & 909366 & 936158 \\
\hline Enterprise value* & 1361 & 2442 & 2678 & 2473 \\
& 629 & 944 & 685 & 686 \\
\hline Net working & -29810 & -183939 & -118741 & -177351 \\
\hline capital & - & 229302 & 226522 & 134788 \\
\hline Free cash flow & 203040 & 284405 & 272334 & 304844 \\
\hline CAPEX & 1204 & 1367 & 1478 & 1511 \\
\hline Revenue & 259 & 588 & 879 & 849 \\
\hline
\end{tabular}

* - cumulative enterprise value (EV) of companies calculated without capitalization of MegaFon and Rostelecom for 2010 .

Key players of the Russian telecommunication industry are PJSC «MTS»; PJSC «Vimpelcom»; PJSC «MegaFon»; PJSC Rostelecom»; LLC «T2 RTK Holding» (with cumulative market volume is more than $80 \%$ ).

Financial indicator analysis of these key companies from 2010 to 2016 demonstrates the following results:

${ }^{1}$ Regions of Russia. Socio-economic indicators. 2016: Stat. Sat. / Rosstat. - M., 2016. - P.863-864.876-879, 890-891

Transport and communications in Russia. 2016: Stat.sb./Rosstat. M., 2016. - 112 p.

${ }^{2}$ Calculated by the authors on the basis of: Information-analytical system SPARK http://www.spark-interfax.ru/.

Annual reports of PJSC "MTS"

http://www.company.mts.ru/comp/ir/control/data/annual_reports/

Annual reports of PJSC "Vympelcom" https://beeline.ru/about/aboutbeeline/disclosure/annual-reports/

Annual reports of PJSC "Megafon" http://corp.megafon.ru/investoram/shareholder/year_report/

Annual reports of the company PJSC "Rostelecom" http://www.rostelecom.ru/ir/disclosure/annual_reports

Financial information on the company LLC "T2 RTK Holding" http://en.tele2.ru/for-investors/russia/fin-info/

Consolidated statements of LLC "T2 RTK Holding" http://en.tele2.ru/for-investors/russia/docs/

Official website of Tele2 Russia (LLC "T2 RTK Holding")

http://en.tele2.ru/for-investors/
- PJSC «MTS» can be assessed as a stable company with an effective management and transparent dividend policy. Dividend yield of shares was $8-10 \%$ for the last years is attractive to investors. The company's business is expected to grow further during the next 3-5 years;

- In general, PJSC «Vimpelcom» is a company with unsustainable financial status and low quality of management;

- PJSC «MegaFon» is attractive for investors. MegaFon has significantly increased its customer's base for the last years to $75 \mathrm{mln}$. in 2015. Company's business shows good operating and financial results - «Return on OIBDA by revenue» in 2015 was $40 \%$. The company's shares show a dividend yield of 7,5\%;

- PJSC «Rostelecom» is a company with stable financial indicators, fair share price. The business of the company is sensitive to the dynamic of the industry as whole;

- «T2 RTK Holding» LLC is a company with negative dynamic of the financial indicators for the last 2-3 years. The probability of exit by this company from market exist. There is also an opportunity to be taken over by the another company with good financial statements from the same industry.

As a result of the review of the Russian telecommunication industry presented in [1], it can be characterized as oligopolistic with a limited number of companies and a high entry barriers.

The following conclusions were made on the base of the analysis of the financial condition of the industry:

- the industry is at a mature growth stage - the growth rate of the revenue have been sharply reduced in recent years (from 2014 the grows rate of revenue was fixed nearly 2\%);

- the debt of the companies in the industry is growing that reflected in growth of financial and net debt from 2010 to 2015;

- the net profit in the industry is also reduced from 2013 by 50 billion per year;

- there is no net working capital in the industry - the value of the same called indicator is negative from 2010 to 2015;

- the fact of structural changes in the telecommunication industry was discovered: driving force changed from mobile services to an electronic document management by the rate of revenue growth;

- the public companies of the industry can be divided into the two groups: the first is high-performance companies aimed at increasing enterprise value and high operating and financial results (MegaFon and MTS); the second is lowperforming companies aimed at achieving strategic goals without strong internal discipline (Rostelecom and Vimpelcom);

- according to the results of 2016, the revenue of the first group of companies (MegaFon and MTS) is expected to grow, while simultaneously reducing its operating and net profits (Table 1).

The telecommunication industry has general growth trend. Such trend demands for the investments because of high degree of depreciation of fixed assets, quite significant portion of loss-making companies, strong growth potential, due to 
high degree of significance of its for accelerating of the development of the neo-industrial regions, reinforced by the needs to move towards the implementation of the National Technological Initiatives and numbers of promising projects. In this case, researching in the area of methodology of the investment analysis of the telecommunication industry is particularly relevant.

\section{THE INDUSTRY INDICATOR FOR TELECOMMUNICATION INDUSTRY}

Investment research is the process of searching, analyzing, evaluating and comparing various investment alternatives for resources released for deferred consumption, taking into account investing objectives. The tools and methods of the investment research may differ for various investment objects. There are two types of analysis possible in case for the financial investments: fundamental and technical analysis. In case of real investment, only fundamental analysis is feasible.

The term "fundamental analysis" was firstly introduced and defined in 1934 in the article "Security analysis" by Americans B. Graham and D. Dodd for the problem of the evaluation of financial investments. Author described fundamental analysis as a tool of forecasting the price of securities (share and bonds) on the stock exchange [2]. Further, the fundamental analysis was studied by such economists as A. Damodaran [3], F. Nite [4], M. Porter [5], G. Soros [6], F. Fabozzi [7, 8], W. Sharp [9] and others [10-13]. Some Russian scientists, T.B. Berdnikova [14], V.A. Galanov [15] and others, also dealt with such issue [16-18].

Analysis of the industry is a part of fundamental analysis and it plays an important role in investment research. The major part of industrial analysis is comparative analysis of financial indicators including the industry indicator. The industry indicator helps to calculate enterprise value on the basis specific industry value-making resources. As rule, it is calculated by dividing EV by the quantity of such valuemaking resources. As a result, indicator estimates the price of the resource unit that creates value. The authors can calculate the fair EV by this indicator. One can estimate EV of the various company's within the same industry using average value of the industry indicator. It is necessary to multiply the average value of the industry indicator to the quantity of value-making resource owned by the company for estimation the fair EV. With a few exceptions, all types of value-making resources can be divided into four groups: reserves, capacity, infrastructure, customer base [19].

The price calculation of the resource unit for the industry requires taking into account the quality of resource unit, especially it is necessary for the service sector. For telecommunication industry where the resource unit is customer (base of customers), the most important quality characteristics are data transfer rate, network coverage geography, quality of customer service etc. Depending on them, the customer is ready to pay bonus for the average market price, or discount, which had an impact on value added cost produced by the company and, as a result, on EV.
In this case, let us propose the analytic indicator for telecommunication industry to express comparative analysis of companies and evaluation of their positions within the industry (formula 1):

Indicator $_{\text {telecom }}=\frac{E V}{A R P U \cdot B a s e O f C u s t o m e r s}$

where $E V$ - enterprise value,

$A R P U$ - average revenue per user,

BaseOfCust omers - number of subscribers (consumers).

This industry indicator helps to find out the fair EV by the resource base of the company, expressed by the quality of customers ( $A R P U$ shows the average ability of customer to pay for the service provided by the operator particular quality of service in the market condition) and its volume ( BaseOfCust omers ).

\section{EVALUATION OF ENTERPRISE VALUE IN}

\section{TELECOMMUNICATION INDUSTRY BY THE INDUSTRY INDICATOR}

The general framework of industrial investment analysis including the industry indicator calculation is very necessary for a practical use. The general scheme of the industrial analysis includes two components: macroeconomic and microeconomic. Macroeconomic industrial analysis includes analysis of global trends, scientific and technical progress. Microeconomic industrial analysis component includes analysis of financial and management statements of the companies of the industry (for oligopolistic market companies forming the industry). This approach not always can be applied in practice because of incompleteness of the information in the industries presented by a large number of private companies. For this reason, it is impossible to aggregate the information of the economic and financial activity in some industries, for example, food or clothing retail.

The calculation of the average and the aggregated financial and economic indicators of the industry plays an important role in generalized scheme of industrial investment analysis (Fig. 1). The generalized scheme of industrial investment analysis as any kind of analysis includes several stages:

1. Collecting and preparation of data for analysis.

2. Calculation of estimated values and other processing of the collected data.

3. Interpretation of the results of processing of the collected data.

Calculation of the aggregated and average values of finance indicators and financial statement values is made by (2) and (3) respectively.

$$
\bar{x}=\frac{1}{n} \sum_{i=1}^{n} x_{i}
$$

where $x_{i}$ - value of $x$ th indicator for $i$ th company, $n$ - number of companies. 


$$
X=\sum_{i=1}^{n} x_{i}
$$

where $x_{i}$-value of $x$ th indicator for $i$ th company, $n$ - number of companies.

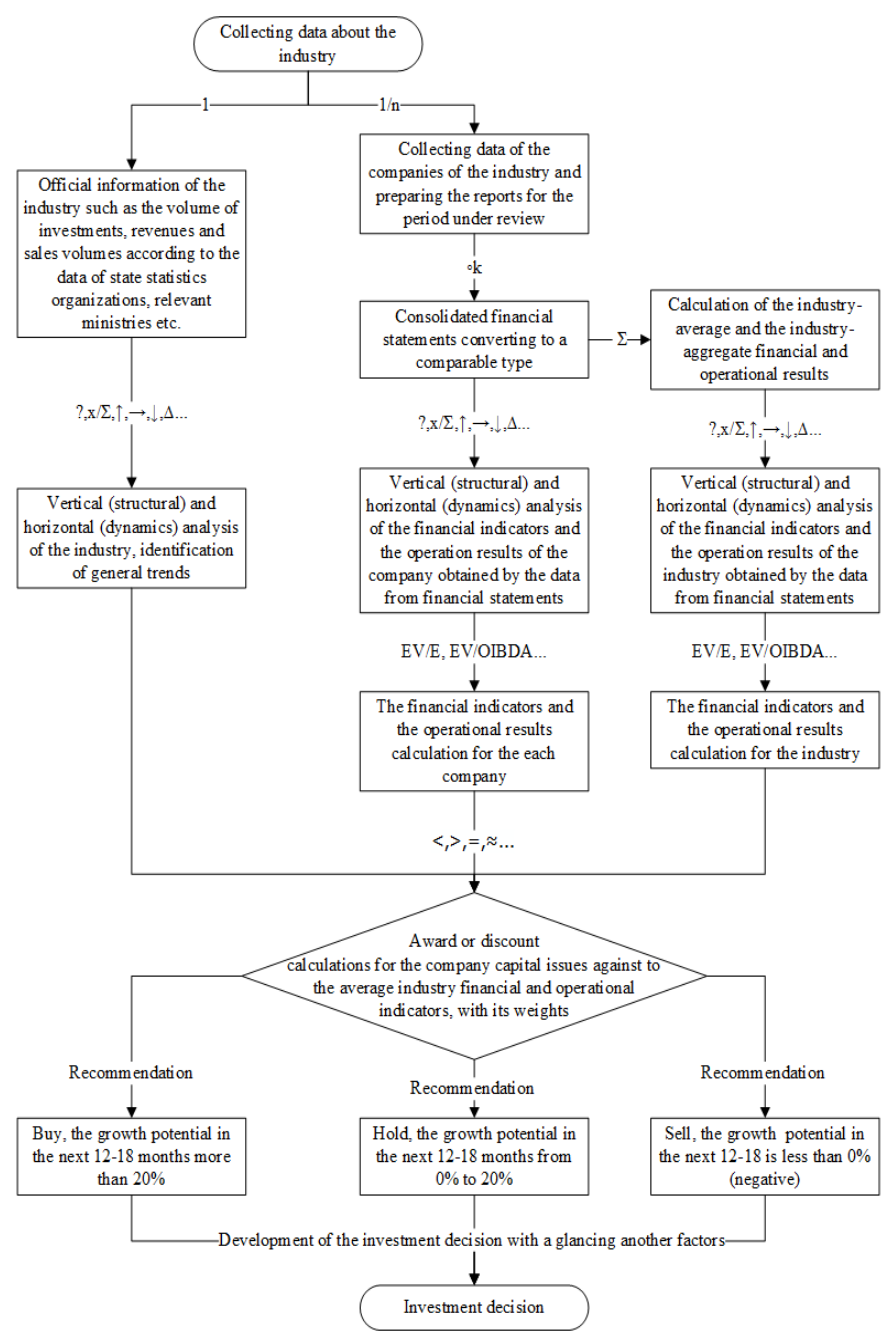

Fig. 1. Generalized scheme of industrial investment analysis Source: designed by authors.

The accuracy of the calculation of the average (2) and aggregated (3) values have direct relation to the cumulative market share of the analyzed companies. In this case, it is recommended to take the number of companies with a cumulative market share of more or equal to $70-80 \%$ from the total market. Otherwise, there is a risk of obtaining unreliable values. The telecommunication industry satisfies condition described above [1].

Summing up, the investment analysis of the industry plays a big role in making an investment decision. It allows considering the features of the investment object itself and comparing it with similar investment objects.

Practical significance of the investment industrial analysis and the industry indicator demonstrated by the telecommunication industry of Russia with the cumulative market share of public companies is ab(20)t, $70-80 \%$.

\section{THE VALUES OF THE GENERALIZED FINANCIAL INDICATORS}

According to table 2, EV/Assets of the industry falls from $1,24 \mathrm{x}$ in 2013 to $0,96 \mathrm{x}$ in 2015 , which shows depreciation of enterprise value to the value of its property. At the same time, Return of OIBDA by income decreased from $40 \%$ in 2013 to $36 \%$ in 2015 . The decline in the industry relates to the beginning of the active expansion of the mobile discounter Tele2 (LLC «T2 RTK Holding») with the value of ARPU $20-25 \%$ lower than the industry average.

TABLE II. INDICATORS, CALCULATED BY FINANCIAL STATEMENT FOR TELECOMMUNICATION INDUSTRY OF RUSSIA3

\begin{tabular}{|c|c|c|c|c|c|c|}
\hline \multirow{2}{*}{ Item } & \multirow{2}{*}{ Unit } & \multicolumn{5}{|c|}{ Year } \\
\cline { 3 - 7 } & & $\mathbf{2 0 1 0}$ & $\mathbf{2 0 1 1}$ & $\mathbf{2 0 1 3}$ & $\mathbf{2 0 1 5}$ & $\mathbf{2 0 1 6} * *$ \\
\hline \multicolumn{2}{|c|}{ INDICATORS (International Financial Reporting Standards) } \\
\hline EV/OIBDA* & - & 2.99 & 4.39 & 4.60 & 4.54 & 4.71 \\
\hline EV/Earnings* & - & 7.19 & 11.15 & 12.18 & 21.54 & 24.43 \\
\hline EV/Assets* & - & 0.74 & 0.97 & 1.24 & 0.96 & 0.98 \\
\hline EV/Sales* & - & 1.13 & 1.54 & 1.84 & 1.64 & 1.64 \\
\hline P/Earnings* & - & 4.93 & 7.23 & 8.67 & 12.70 & 13.88 \\
\hline P/Sales* & - & 0.78 & 1.00 & 1.31 & 0.97 & 0.93 \\
\hline P/BV* & - & 1.07 & 1.50 & 2.64 & 1.56 & 1.54 \\
\hline $\begin{array}{c}\text { Net debt / } \\
\text { OIBDA }\end{array}$ & - & 1.28 & 1.63 & 1.33 & 1.86 & 2.03 \\
\hline $\begin{array}{c}\text { Return of } \\
\text { OIBDA by } \\
\text { income }\end{array}$ & $\%$ & $38 \%$ & $35 \%$ & $40 \%$ & $36 \%$ & $35 \%$ \\
\hline Indicator (t) & & 25 & 33 & 40 & 34 & $32 * * *$ \\
\hline
\end{tabular}

* - financial indicators calculated based of capitalization $(\mathrm{P})$ and enterprise value (EV) excluding capitalization of MegaFon from 2010 to 2011 and Rostelecom in 2010.

** - financial indicators calculated excluding forecasting values of financial statements in 2016 for LLC «T2 RTK Holding».

*** - the industry indicator calculated based on the assumption of ARPU value and customer base will stay at the level of prior year.

Source: designed by author.

The aggregated values of indicators of the telecommunication industry of Russia (including LLC «T2 RTK Holding») will be used at the next step. The comparative analysis was done for the public traded companies.

3 Calculated by the authors on the basis of: Information-analytical system SPARK http://www.spark-interfax.ru/ Annual reports of PJSC "MTS"

http://www.company.mts.ru/comp/ir/control/data/annual_reports/.

Annual reports of PJSC "Vympelcom" https://beeline.ru/about/about-beeline/disclosure/annual-reports/ Annual reports of PJSC "Megafon" http://corp.megafon.ru/investoram/shareholder/year_report/

Annual reports of the company PJSC "Rostelecom" http://www.rostelecom.ru/ir/disclosure/annual_reports/.

Information on the company LLC "T2 RTK Holding" http://en.tele2.ru/for-investors/russia/fin-info/

Consolidated statements of LLC "T2 RTK Holding" http://en.tele2.ru/for-investors/russia/docs/

Official website of Tele2 Russia (LLC "T2 RTK Holding") http://en.tele2.ru/for-investors/ 


\section{COMPARATIVE ANALYSIS OF THE INDUSTRY INDICATOR FOR} EXPRESS-EVALUATION WITH OTHER FINANCIAL INDICATORS

Discount analysis of the companies was done by the indicators with EV value in the enumerator (Table 3). The foreign studies has shown that this type of evaluation does not always give an accurate forecast of the fair enterprise value.

TABLE III. DISCOUNT (BONUS) ON THE ENTERPRISE VALUE OF THE COMPANIES TO THE INDUSTRY AVERAGE VALUES FOR TELECOMMUNICATION INDUSTRY OF RUSSIA FROM 2012 TO 2016.4

\begin{tabular}{|c|c|c|c|c|c|}
\hline $\begin{array}{c}\text { Compan } \\
\mathbf{y} \\
\end{array}$ & Discount base & 2012 & 2014 & 2015 & 2016* \\
\hline \multirow{7}{*}{ MTS } & EV/OIBDA & $-14 \%$ & $-11 \%$ & $-2 \%$ & $9 \%$ \\
\hline & EV/Earnings & $49 \%$ & $-11 \%$ & $-23 \%$ & $-9 \%$ \\
\hline & EV/Assets & $27 \%$ & $23 \%$ & $25 \%$ & $43 \%$ \\
\hline & EV/Sales & $-1 \%$ & $1 \%$ & $11 \%$ & $18 \%$ \\
\hline & Average & $15 \%$ & $1 \%$ & $3 \%$ & $15 \%$ \\
\hline & $\begin{array}{l}\text { Real growth of } \\
\text { EV for the next } \\
\text { year }\end{array}$ & $-1 \%$ & $11 \%$ & $12 \%$ & - \\
\hline & Indicator $(\mathrm{t})$ & $-16 \%$ & $-19 \%$ & $-8 \%$ & $9 \%$ \\
\hline \multirow{7}{*}{$\begin{array}{c}\text { Vimpelco } \\
\text { m }\end{array}$} & EV/OIBDA & $9 \%$ & $-6 \%$ & $-23 \%$ & $-35 \%$ \\
\hline & EV/Earnings & $-36 \%$ & $-2 \%$ & $-2 \%$ & $-13 \%$ \\
\hline & EV/Assets & $-33 \%$ & $-29 \%$ & $-30 \%$ & $-45 \%$ \\
\hline & EV/Sales & $-17 \%$ & $-9 \%$ & $-26 \%$ & $-36 \%$ \\
\hline & Average & $-19 \%$ & $-12 \%$ & $-20 \%$ & $-32 \%$ \\
\hline & $\begin{array}{l}\text { Real growth of } \\
\text { EV for the next } \\
\text { year }\end{array}$ & $15 \%$ & $5 \%$ & $-17 \%$ & - \\
\hline & Indicator $(\mathrm{t})$ & $-34 \%$ & $-14 \%$ & $-28 \%$ & $-37 \%$ \\
\hline \multirow{7}{*}{ MegaFon } & EV/OIBDA & $6 \%$ & $29 \%$ & $32 \%$ & $24 \%$ \\
\hline & EV/Earnings & $5 \%$ & $35 \%$ & $-12 \%$ & $-11 \%$ \\
\hline & EV/Assets & $38 \%$ & $75 \%$ & $66 \%$ & $31 \%$ \\
\hline & EV/Sales & $17 \%$ & $41 \%$ & $46 \%$ & $23 \%$ \\
\hline & Average & $16 \%$ & $45 \%$ & $33 \%$ & $17 \%$ \\
\hline & $\begin{array}{l}\text { Real growth of } \\
\text { EV for the next } \\
\text { year }\end{array}$ & $37 \%$ & $4 \%$ & $-13 \%$ & - \\
\hline & Indicator $(\mathrm{t})$ & $-28 \%$ & $-2 \%$ & $-8 \%$ & $-15 \%$ \\
\hline \multirow{5}{*}{$\begin{array}{c}\text { Rosteleco } \\
\mathrm{m}\end{array}$} & EV/OIBDA & $6 \%$ & $-10 \%$ & $-8 \%$ & $2 \%$ \\
\hline & EV/Earnings & $21 \%$ & $-29 \%$ & $34 \%$ & $98 \%$ \\
\hline & EV/Assets & $-12 \%$ & $-21 \%$ & $-21 \%$ & $-20 \%$ \\
\hline & EV/Sales & $5 \%$ & $-23 \%$ & $-15 \%$ & $-8 \%$ \\
\hline & Average & $5 \%$ & $-21 \%$ & $-2 \%$ & $18 \%$ \\
\hline
\end{tabular}

${ }^{4}$ Calculated by the authors on the basis of: Information-analytical system SPARK http://www.spark-interfax.ru/

Annual reports of PJSC "MTS" http://www.company.mts.ru/comp/ir/control/data/annual_reports/ Annual reports of PJSC "Vympelcom" https://beeline.ru/about/aboutbeeline/disclosure/annual-reports/

Annual reports of "Megafon" http://corp.megafon.ru/investoram/shareholder/year_report/

Annual reports of the company PJSC "Rostelecom" http://www.rostelecom.ru/ir/disclosure/annual_reports/

Financial information on the company LLC "T2 RTK Holding" http://en.tele2.ru/for-investors/russia/fin-info/

Consolidated statements of LLC "T2 RTK Holding" http://en.tele2.ru/for-investors/russia/docs/

Official website of Tele2 Russia (LLC "T2 RTK Holding") http://en.tele2.ru/for-investors/

\begin{tabular}{|c|c|c|c|c|c|}
\hline & $\begin{array}{c}\text { Real growth of } \\
\text { EV for the next } \\
\text { year }\end{array}$ & $-13 \%$ & $-18 \%$ & $8 \%$ & - \\
\cline { 2 - 5 } & Indicator $(\mathrm{t})$ & & - & - & - \\
\hline
\end{tabular}

Source: designed by author.

In some studies, the conclusions were drawn that fundamental assessments have a lagged effect on EV [20]. In others studies it was shown that the EV formation is based on the investors' expectations [21]. However, despite the validity of both conclusions, in practice, institutional and private investors use a standard set of indicators to assess the value of the company.

According to table 2, MegaFon historically had the bonus of the average market price of about $30 \%$, due to high quality of management and high speed of growth of the customers base (by the official annual reports customers base increased from $57 \mathrm{mln}$. in 2010 to $75 \mathrm{mln}$. in 2015). In 2016, the reduction of the bonus of the $\mathrm{EV}$ to the average industry values is forecasted to be at $17 \%$ above the market.

Outsider of the telecommunication industry, there is Vimpelcom with the discount up to 20\% (in 2015), due to the uncertainty of the investors about the future of the company and the poor quality of management.

The EV of MTS is close to the equitable value, with a little bonus in 2014 and 2015. Taking into account the company's operating results and the history of dividend payments, the EV of MTS is underestimated.

TABLE IV. CORRELATION OF DISCOUNTS ON THE ENTERPRISE VALUE OF THE COMPANIES OF THE TELECOMMUNICATION INDUSTRY OF RUSSIA FROM 2012 Tо 2016

\begin{tabular}{|c|c|c|c|c|c|c|c|}
\hline $\begin{array}{c}\text { Pair } \\
\text { corre } \\
\text { latio } \\
\text { ns }\end{array}$ & $\begin{array}{l}\text { EV/ } \\
\text { OIB } \\
\text { DA }\end{array}$ & EV/E & $\begin{array}{c}\text { EV/A } \\
\text { ssets }\end{array}$ & EV/S & $\begin{array}{c}\text { Aver } \\
\text { age }\end{array}$ & EV & $\begin{array}{c}\text { Indic } \\
\text { ator } \\
\text { (t) }\end{array}$ \\
\hline $\begin{array}{c}\mathrm{EV} / \mathrm{O} \\
\mathrm{IBD} \\
\mathrm{A}\end{array}$ & 1 & 0.517 & 0.519 & 0.813 & 0.856 & $\begin{array}{c}- \\
0.213\end{array}$ & 0.715 \\
\hline $\mathrm{EV} / \mathrm{E}$ & 0.517 & 1 & 0.253 & 0.412 & 0.689 & $\begin{array}{c}- \\
0.161\end{array}$ & 0.717 \\
\hline $\begin{array}{c}\mathrm{EV} / \mathrm{A} \\
\text { ssets }\end{array}$ & 0.519 & 0.253 & 1 & 0.881 & 0.803 & 0.147 & 0.703 \\
\hline $\mathrm{EV} / \mathrm{S}$ & 0.813 & 0.412 & 0.881 & 1 & 0.934 & $\begin{array}{c}- \\
0.062\end{array}$ & 0.850 \\
\hline $\begin{array}{c}\text { Aver } \\
\text { age }\end{array}$ & 0.856 & 0.689 & 0.803 & 0.934 & 1 & $\begin{array}{c}- \\
0.083 \\
\end{array}$ & 0.859 \\
\hline EV & $\begin{array}{c}- \\
0.213\end{array}$ & $\begin{array}{c}- \\
0.161\end{array}$ & 0.147 & $\begin{array}{c}- \\
0.062\end{array}$ & $\begin{array}{c}- \\
0.083\end{array}$ & 1 & $\begin{array}{c}- \\
0.268\end{array}$ \\
\hline $\begin{array}{l}\text { Indic } \\
\text { ator } \\
\text { (t) }\end{array}$ & 0.715 & 0.717 & 0.703 & 0.850 & 0.859 & $\begin{array}{c}- \\
0.268\end{array}$ & 1 \\
\hline
\end{tabular}

** - Correlations with statistical significance at level 0,01 (2-side).

* - Correlations with statistical significance at level 0,05 (2- side).

Source: designed by authors using data from table 2 .

Rostelecom had a discount to market value due to nonrational use of well-developed infrastructure and the biggest network. The management of the company has not been using the full potential of the assets: the value of EV/Assets from 2012 to 2015 has a discount about $20 \%$. 
In addition to discount, the authors conducted calculation, correlation analysis of the discount with a different base using Pearson's correlation coefficient (Table 4). Calculation was made by IBM SPSS version 21. Correlation analysis showed the strong bond (correlation coefficient is 0.7 , p-value less then 0.01 ) between all the discounts with standard base indicators and the discount calculated by the proposed industry indicator (formula 1). The strongest bond was established between the average discount rate and the discount based on the industry indicator (correlation coefficient is 0,895 p-value - less than 0.01).

\section{CONCLUSION}

The proposed scheme of industrial investment analysis includes two important components: macroeconomic and microeconomic. Macroeconomic industrial analysis includes analysis of global trends, scientific and technical progress. Microeconomic industrial analysis component includes analysis of financial and management statements of the companies of the industry (for oligopolistic market companies forming the industry).

The developed industry indicator (Indicator $r_{\text {telecom }}$ ) is useful for express-evaluation of EV of the companies of the telecommunication industry and it can replace the standard set of the financial indicators (EV/OIBDA, EV/E, EV/Assets, $\mathrm{EV} / \mathrm{S}$ ). It is also useful for comparative analysis and making an investment decision.

The review of the telecommunication industry of Russia showed that the industry passed the stage of rapid growth in 2010. Nowadays, the telecommunication industry is at the stage of mature growth determined by the current economic situation. At this stage, the long-term nature of the industry development is manifested. Therefore, it is typical for the industry to bring returns with the middle risk for the mediumterm (from 1 to 3 years) and the long-term ( $3-5$ years and more) investments.

Industry analysis made it possible to determine the characteristics of investments: risk (medium-risk), terms of investment (medium and long-term), control over investments (minority and strategic), investment purpose (create value and speculative), investment-attractive companies (MTS, MegaFon).

\section{References}

[1] L.D. Zubkova, S.M. Dyachkov, "Analysis of investment attractiveness of the telecommunication industry", Economy and entrepreneurship Economy and entrepreneurship, vol. 4-1 (57-1), 819-823, 2015.

[2] S. Cottle, R.F. Murray, F.E. Blok, "Securities Analysis", Moscow, ZAO Olimp - Business, 2000, p. 704.

[3] A. Damodaran, "Investment assessment", Moscow, Alpina Business Books, 2004, 1322 p.

[4] F. Nite, "Risk, uncertainty and profit", Moscow, Business, 2003, 360 p.

[5] M. Porter, "Competitive strategy: Technique analyzing industries and competitors", Moscow, Alpina Business Books, 2005, 454 p.

[6] G. Soros, "Soros about Soros. Ahead of change", Moscow, INFRA-M, 1996, 336 p.
[7] F.J. Fabozzi, "Bond Market: Analysis and strategy", Moscow, Alpina Business Books, 2007, 950 p.

[8] F. Fabozzi, "Financial instruments", Moscow, Eksmo, 2010, 864 p.

[9] W.F. Sharp, G.D. Alexander, J.V. Bailey, "Investments", Moscow, INFRA-M, 2009, 1028 p.

[10] J.D. Piotroski, C.S. Eric, "Identifying Expectation Errors in Value/Glamour Strategies: A Fundamental Analysis Approach. Review Finance Studies, vol. 25 (9), pp. 2841-2875, 2012.

[11] H. Pan, D. Sornette, K. Kortanek, "Intelligent finance-an emerging direction”, Quantitative Finance, vol. 6, pp. 273-277, 2006.

[12] D. Bryan, M. Rafferty. "Fundamental value: a category in transformation", Economy and Society, vol. 42, pp. 130-153, 2013.

[13] M.-M. Lai, S.-H. Tan, L.-L. Chong, "The Behavior of Institutional and Retail Investors in Bursa Malaysia during the Bulls and Bears", Journal of Behavioral Finance, vol. 14, pp. 104-115, 2013.

[14] [14] T.B. Berdnikova "Securities Market: past, present, future", Moscow: INFRA-M, 2011, 397 p.

[15] [15] V.A. Galanov, "Securities Market", Moscow: INFRA-M, 2006, 379 p.

[16] J. Doležal, J. Šnajdr, J. Belás, Z. Vincúrová, "Model of the loan process in the context of unrealized income and loss prevention", Journal of International Studies, vol. 8 (1), pp. 91-106, 2015.

[17] J. Gazda, "Real business cycle theory - Methodology and tools", Economics and Sociology, vol. 3 (1), pp. 42-48, 2010.

[18] E. Lisin, G. Kurdiukova, W. Strielkowski, "Economic prospects of the power-plant industry development in Russia", Journal of International Studies, vol. 9(3), pp. 178-190, 2016.

[19] UK "Arsagera", "Notes to investing: a book about investing and managing capital", SPb. Svoe izdatelstvo, 2015, 496 p.

[20] H. Hong, W.Torous, R. Valkanov. "Do industries lead stock markets?", Journal of Financial Economics, vol. 83, Issue 2, pp. 367-396, 2007.

[21] J. Liu, D .Nissim, J. Thomas. "Equity Valuation Using Multiples", Journal of Accounting Research, vol. 40(1), pp.135-172, 2002. 